\title{
Holocene uplift and palaeoseismicity on the Eliki Fault, Western Gulf of Corinth, Greece
}

\author{
Iain Stewart $(*)$ \\ Neotectonics Research Centre, Department of Geography and Earth Sciences, Brunel University, \\ Isleworth, London, U.K.
}

\begin{abstract}
Radiocarbon dating of elevated coastal phenomena along the emergent footwall of the Eliki Fault in the Western Gulf of Corinth has established a chronology of tectonic emergence during Holocene times. The results confirm $\sim 6 \mathrm{~m}$ of coastal uplift over the last 3000 years at sites both immediately adjacent to, and more distant from, the offshore fault. Although revealing little or no spatial variation along the fault, temporally the data define two phases of enhanced tectonic activity (0-3000 year B.P. and pre-7-8000 year B.P.) separated by a 45000 year period of tectonic quiescence. Well documented historical surface faulting during the most recent active phase testify to the contribution to net uplift played by coseismic increments, but these are considered to be superimposed on significant aseismic movements. While asesismic uplift confuses the palaeoseismic surface faulting events during the past 2500 years.
\end{abstract}

Key words palaeoseismology - normal faulting Holocene sea-level change $-{ }^{14} \mathrm{C}$ dating - Greece

\section{Introduction}

The southern shores of the Western Gulf of Corinth, Greece, have been affected by numerous historical earthquakes (Ambraseys and Jackson, 1990), many of them in the vicinity of a prominent coastal-bounding fault system between Aegion and Aegira; the Eliki Fault (Poulimenos, 1993) (fig. 1a). Geological and geomorphic evidence indicate Holocene activity on this fault, and the two significant historical earthquakes recorded within this area, those in 373 B.C. and A.D. 1861, are attributed to reactivation of this structure (Mouyaris et al., 1992; Poulimenos, 1993). If this is correct, the Eliki Fault is among one of the few docu-

\footnotetext{
(*) e-mail: iain.stewart @ brunel.oc.uk
}

mented active normal fault in the Aegean region to have ruptured in consecutive earthquake events within the historical timespan; a fact that has important implications for estimates of earthquake recurrence intervals in this region. Furthermore, coastal studies along the fault provide geological evidence of longer term tectonic activity which can be usefully compared with historical records (Mouyaris et al., 1992). This paper documents the magnitude and timing of Holocene coastal emergence along the Eliki Fault in an attempt to establish whether such data can be used to reconstruct the fault's palaeoseismic history.

\section{Surface faulting along the Eliki Fault}

Although earthquake-related surface movements are widely reported for the 373 B.C. Helice earthquake by classical scholars (cited in Karfakis and Mouyaris, 1988 and Mouyaris et al., 1992), Schmidt's (1879) account of the 


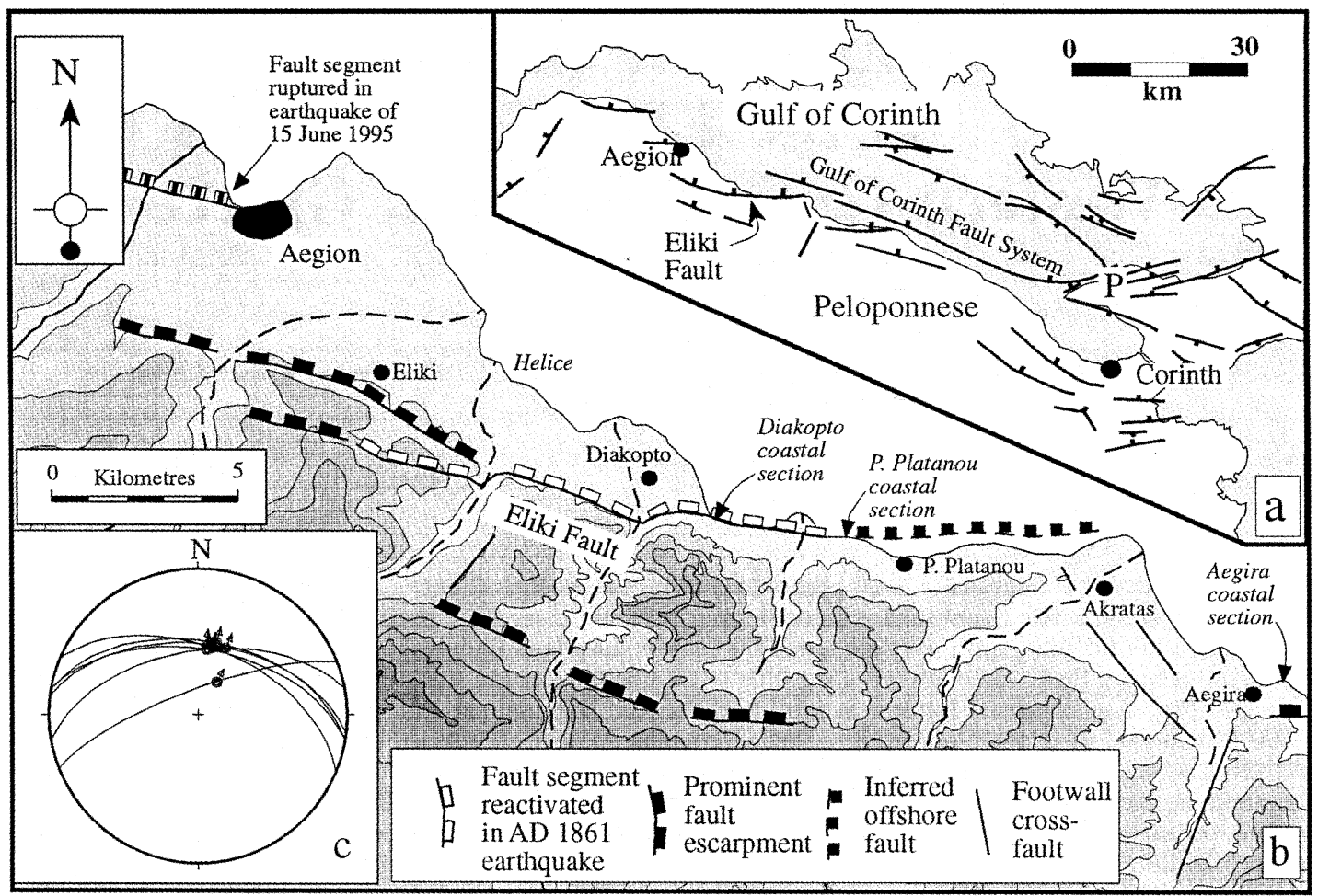

Fig. 1. Location maps showing: a) position of the Eliki Fault within the Gulf of Corinth fault system, Central Greece; b) the trace of the 1861 surface break on a topographic map of the Aegion-Aegira coastal strip. Contours are at $100 \mathrm{~m}$ intervals. Inferred position of the ancient city of Helice and location of the studied coastal sections are shown in italics; c) shows a lower-hemisphere stereoplot of fault striations measured from a bedrock fault plane exposed immediately south of Eliki.

26 December 1861 earthquake is the first clear description of surface faulting along the Eliki Fault. According to Schmidt (1879), a surface break, in places up to $2.4 \mathrm{~m}$ high and $1.8 \mathrm{~m}$ wide, can be traced from south of Eliki eastwards to the coast beyond Diakopto (fig. 1b): a distance of $\sim 13.5 \mathrm{~km}$. The trace of the fault is clearly segmented, comprising three $3-5 \mathrm{~km}$ long linear sections separated by two sharp left-stepping $0.5-1 \mathrm{~km}$ wide jogs. At localities immediately south and south west of Eliki, $20 \mathrm{~m}$ high limestone fault planes preserve frictional-wear striae and metre-scale corrugations indicating almost pure dip-slip fault movement (fig. 1c) consistent with the N-S extension recorded elsewhere in this part of the Gulf of
Corinth (Jackson, 1994 and references therein). These bedrock fault planes show no sign of reactivation in the 1861 event. Further east along the base of the fault escarpment, 1.5-5 m high scarps cutting indurated colluvial deposits discontinuously follow the line of Schmidt's 1861 rupture and are considered here the probable expression of the active fault trace. Detailed field surveys carried out following the Aegion earthquake of 15 June 1995 reveal no evidence for reactivation of the Eliki Fault, with minor surface breaks instead occurring along a normal fault segment to the north (Roberts and Koukouvelas, 1996).

East of Diakopto, a linear coastal escarpment and steep offshore bathymetry suggest 
that the main Eliki Fault segment continues immediately offshore, at least as far as Akratas (Ferentinos et al., 1988). Although there is no information concerning whether this submarine portion of the fault was reactivated in 1861, elevated shoreline notches along this coast were interpreted as evidence of recent episodic tectonic uplift (Mouyaris et al., 1992). In particular, radiocarbon dating of emergent marine borer shells (L. lithophaga) associated with these notches suggested «... that there has been emergence by at least $6.5 \mathrm{~m}$ in the last 4880 years which, given three uplift events, amounts to an average of just over $2 \mathrm{~m}$ every 1600 years» (Mouyaris et al., 1992, p. 128). The implication, therefore, is that the offshore portion of the Eliki Fault remains tectonically active.

\section{Morphological evidence for coastal emergence along the Eliki Fault}

Field surveys of the coast between Diakopto and Aegira reveal a number of sites where evidence of recent coastal emergence was preserved (fig. 2), some of which are previously reported (Mouyaris et al., 1992; Vita-Finzi, 1993). In particular, two types of marine phenomena were recorded: 1) elevated erosional notches, and 2) raised marine fauna.

\subsection{Elevated erosional notches}

Well developed notches in bedrock have been widely employed as palaeo-sea-level indicators in studies of active coastal faulting in the Aegean region (e.g., Pirazzoli, 1986; Stiros et al., 1992; Pirazzoli et al., 1994). They are at best often ambiguous markers, since even where correlated with dated marine fauna ancient notch horizons may be reoccupied by recent organisms to yield a misleadingly youthful age. Notches, however, are most reliable where they display a fresh, well-defined form and consistent arrangement between sites. Along the Eliki Fault, erosional notches were documented at three sites: 1) immediately east of Diakopto; 2) on the rocky limestone coast east of Paralia Platanou, and 3) on a isolated limestone headland south of Aegira (fig. 2). At all three sites, elevations of the notches were

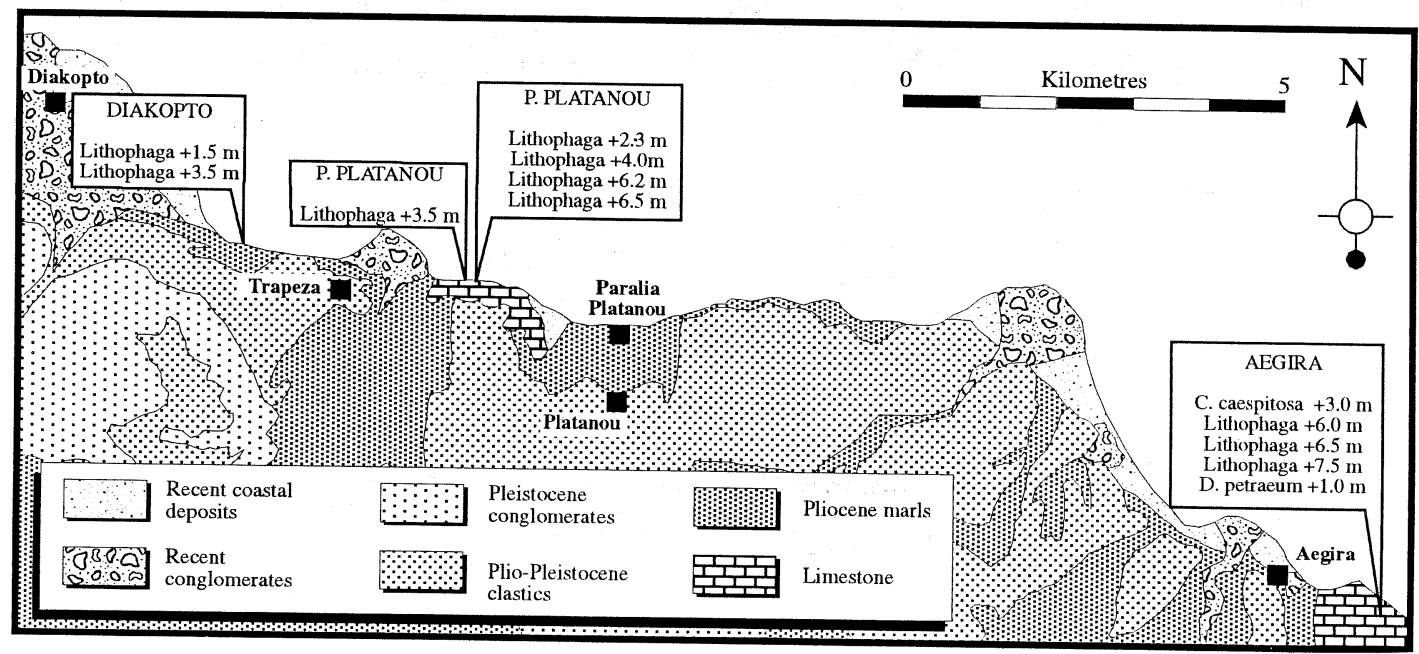

Fig. 2. Simplified geology of the coastal strip between Diakopto and Aegira annotated to indicate the location of the main coastal sites discussed in the paper. Boxes show the present-day height and type of shoreline fauna dated in this study and listed in table I. 
defined in relation to «biological mean sealevel» (Laborel and Laborel-Duegen, 1994) and their detailed form profiled using an $\mathrm{Ab}$ ney level and $0.5 \mathrm{~m}$ measuring tape.

Several kilometres east of Diakopto (fig. 2), well-defined notches are cut into comparatively-indurated beach conglomerate. Although expressed as a series of low isolated blocks at the western end, towards the east the upper surface of the conglonerate forms a flat platform at an elevation of about $6 \mathrm{~m}$. Systematic measurements of notch elevations at this site reveal a prominent notch level at $\sim+1.7 \mathrm{~m}$ above sea level, and less well-defined undercuts at elevations of $+0.5,+2.3$ and $+3.7 \mathrm{~m}$ above (fig. 3). The site, which lies a few hundred metres east of the prominent onshore expression of the Eliki Fault, is coincident with Schmidt's 1861 rupture trace and the steep (70-dipping), east-west striking seaward face of the conglomerate platform is likely to constitute the emergent fault plane itself. Evidence for this can be found in the highly cemented and brecciated nature of the conglomerate within a cm-wide zone immediately adjacent to the scarp face, a feature that resembles compact fault breccias described from normal faults elsewhere in the Aegean region (Stewart and Hancock, 1990). Minor faults offsetting the flat platform surface within a few metres of the coastal scarp, support the contention of recent reactivation along this structure.

About $1 \mathrm{~km}$ east of Paralia Platanou, and several kilometers east of the apparent termination of the 1861 rupture trace (fig. 2), fallen limestone blocks preserved as small headlands exhibit prominent erosional notches at various levels (Mouyaris et al., 1992; Vita-Finzi, 1993)

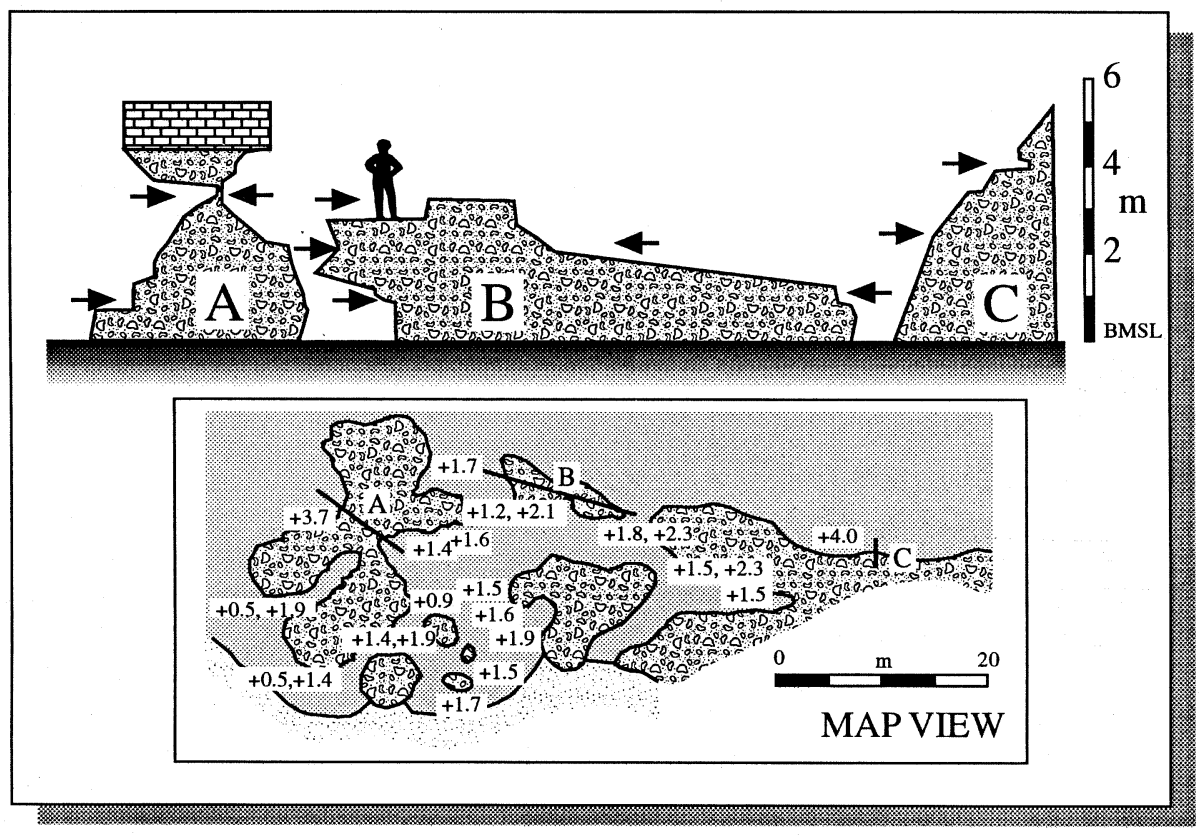

Fig. 3. Series of coastal profiles (A-C) showing the morphology of erosional levels cut into a fragmented indurated conglomerate beachrock platform east of Diakopto. Scale shown by vertical graduated bar (no vertical exaggeration), but figure shown for indicative scale. BMSL - Biological Mean Sea-Level. Map view shows the location of the three profiles relative to a plan of the beachrock platform. Values represent the elevation in metres of prominent undercuts at various points. 


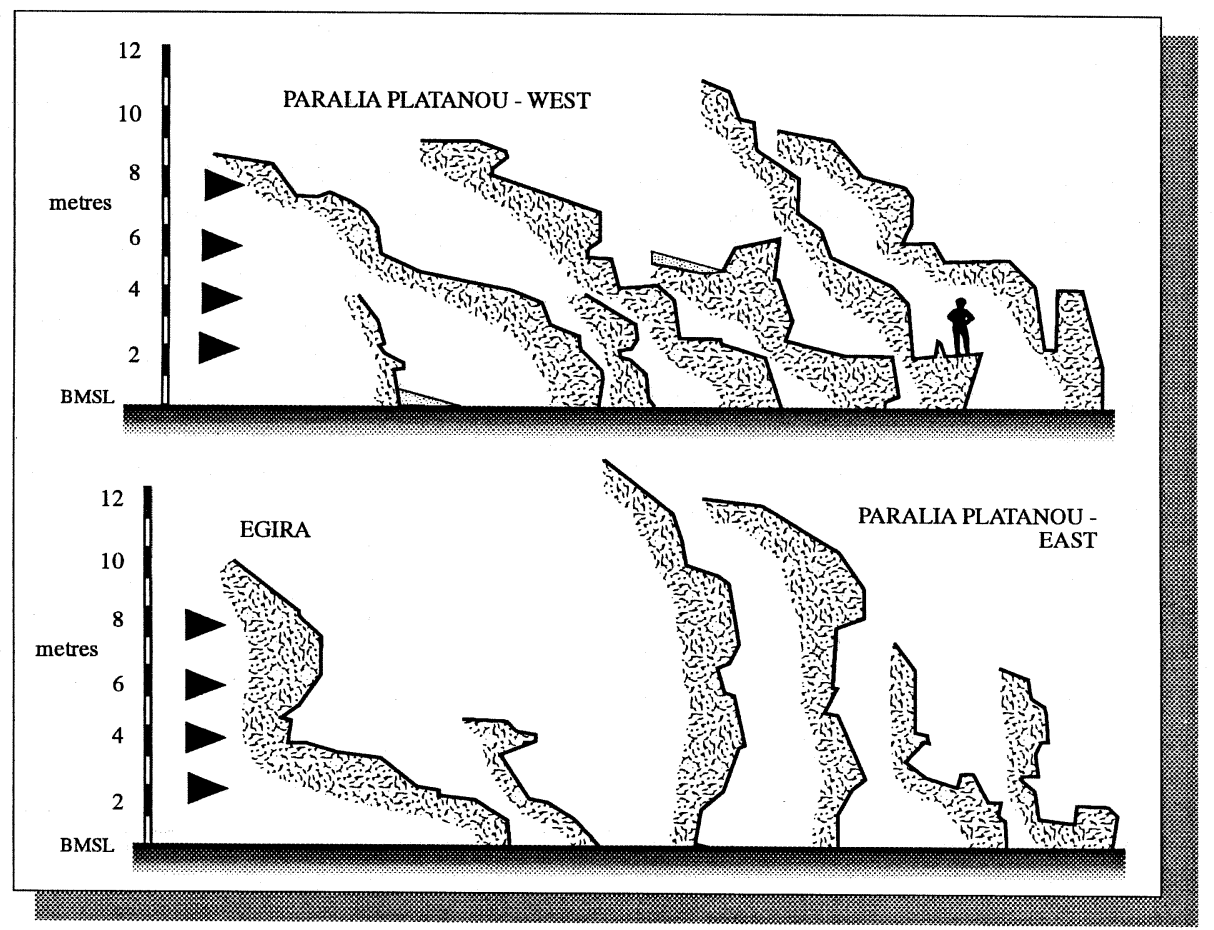

Fig. 4. Coastal profiles at Paralia Platanou (east and west) and Aegira showing the inferred position (arrowheads) of prominent erosional levels cut into the limestone cliffs. Scale shown by vertical graduated bar (no vertical exaggeration), but figure shown for indicative scale. BMSL - Biological Mean Sea-Level.

(fig. 4). Profiles of the limestone blocks reveal considerable variability in form along strike, but provide some support for consistent undercuts at elevations of $+1.8-2.0,+3.5-3.7,+5.5$, and $+7.5 \mathrm{~m}$ above sea-level, in order of decreasing reliability. Along the westermost limestone headland, the lowermost 4-6 $\mathrm{m}$ of the otherwise highly irregular rocky face is expressed as a steep, planar scarp, suggesting that this is the coastal expression of a fault contiguous with the shore.

Several kilometres south of the inferred offshore extension of the Eliki Fault, an isolated headland of brecciated limestone near Aegira is partially draped by a carapace of calcareous, fossiferous Quaternary marine deposits (Mouyaris et al., 1992; Vita-Finzi, 1993). The irregular, patchy form of the carapace obscures the underlying bedrock morphology, though prominent benches are displayed at elevations of $\sim+3.0, \sim+5.2$ and $\sim+6.8 \mathrm{~m}$. Where the carapace has been removed, profiles indicate a prominent notch at $+3.5-3.7 \mathrm{~m}$ and a marked break in slope at $\sim+1.8 \mathrm{~m}$ (fig. 4 ).

In summary, morphological evidence along the Eliki Fault demonstrates prominent erosional levels at +1.8 and $+3.7 \mathrm{~m}$ above present day sea level at all three sites studied, while levels at +2.3 and $+5.5 \mathrm{~m}$ can be detected at all but Aegira. Less consistently defined along the Eliki Fault are minor notches at elevations of $+0.5,+5.5$ and $+7.5 \mathrm{~m}$. In comparison, Mouyaris et al. (1992) noted distinct erosion levels at +1.7 and $5.7 \mathrm{~m}$ near Paralia Platanou and at $+2.2,+4.5$ and $+5.7 \mathrm{~m}$ near Aegira. 


\subsection{Radiometric dating of raised marine fauna}

Emergent marine fauna have been identified from several localities along the Eliki Fault (fig. 2) and reported in a number of previous studies (table I). Subsequent radiometric dating of this fauna has largely been carried out by conventional ${ }^{14} \mathrm{C}$ and AMS dating of in situ shells of L. lithophaga (Mouyaris et al., 1992; Stewart and Vita-Finzi, 1996), a boring mollusc widely used in studies of active coastal tectonics because the upper limit of borings is a reliable indicator of mean sea-level (Stiros et $a l .$, 1992). Lithophaga-derived dates are augmented by an AMS date on a sample of the upper tidal-dwelling vermetid Dendropoma petraeum (Papageorgiou et al., 1993), and by Useries dating of a shallow-water coral (Cladocora caespitosa) (Vita-Finzi, 1993).

While the sample preparation for the nonlithophaga dates are discussed in Papageorgiou et al. (1993) and Vita-Finzi (1993), lithophaga samples were screened for contamination using $X$-ray diffraction supplemented by light and scanning electron microscopy. The age data were calibrated to calendar years using the CALIB programme (Stuiver and Reimer, 1993), incorporating a reservoir age of 320 years $(\Delta R=-80 \pm 25$ years $)$ following Stiros et al. (1992). The elevation data were corrected for palaeo-sea-level changes using the Holocene eustatic curve for the Mediterranean region of Flemming and Webb (1986). It is noted, however, that uplift rates derived from this curve are likely to be minimum rates, since the curve used predicts lower amplitude eustatic sea-level changes than global sea-level curves (Fairbanks, 1989; Blanchon and Shaw, 1995), whose applicability to the Mediterranean region has yet to be established.

\section{Coastal uplift and fault segmentation}

The Eliki Fault comprises part of a belt of roughly E-W trending active normal faults which together form the western end of the Gulf of Corinth fault system (Roberts and Jackson, 1991; Roberts and Koukouvelas,
1996). According to some structural studies, the right-stepping segmentation of the coastalbounding normal fault system in this western sector is accommodated by NNE-trending cross-faults transferring displacement between offset normal fault segments (Doutos and Poulimenos, 1992; Poulimenos, 1993). A major «transfer zone» is identified between Akratas and Aegira, across which contrasting sedimentary sequences are reported (Poulimenos et al., 1989; Dart et al., 1994). A marine seismic reflection profile crossing the line of the Eliki Fault east of Akratas shows little or no bathymetric expression of this structure here (Ferentinos et al., 1988), supporting the contention that fault displacement is reduced substantially in this area in a manner consistent with Akratas marking the eastern end of the Eliki Fault segment. It is noteworthy, however, that Roberts and Koukouvelas (1996) argue that, in structural terms, the Eliki Fault segment as defined here is part of a longer coherent structural unit.

Determining the pattern of fault segmentation in the study area is important because the along-strike structure of an active normal fault exerts considerable control on the distribution of coseismic slip (Crone et al., 1987) and, in the long-term, of cumulative uplift along the emerging footwall crest (Zhang et al., 1991; Roberts and Gawthorpe, 1994). In particular, dislocation theory dictates that the extent of footwall emergence is greatest along the central portion of a fault segment and decreases both laterally towards its fault tips and with increasing distance into the footwall (e.g., Roberts and Koukouvelas, 1996). It follows that shoreline indicators elevated in the footwall of the central portion of a fault segment will experience greater uplift rates (and higher fault-slip rates) than phenomena of equivalent age raised near the fault tip. Within the stepover or transfer zone between overlapping fault segments, both the rate and sense of net elevation change may be obscured.

Along the Eliki Fault, Holocene uplift data is available for two coastal sites in the immediate footwall of the main fault segment (Diakopto and Paralia Platanou) and one site in an inferred transfer zone in the footwall of the 


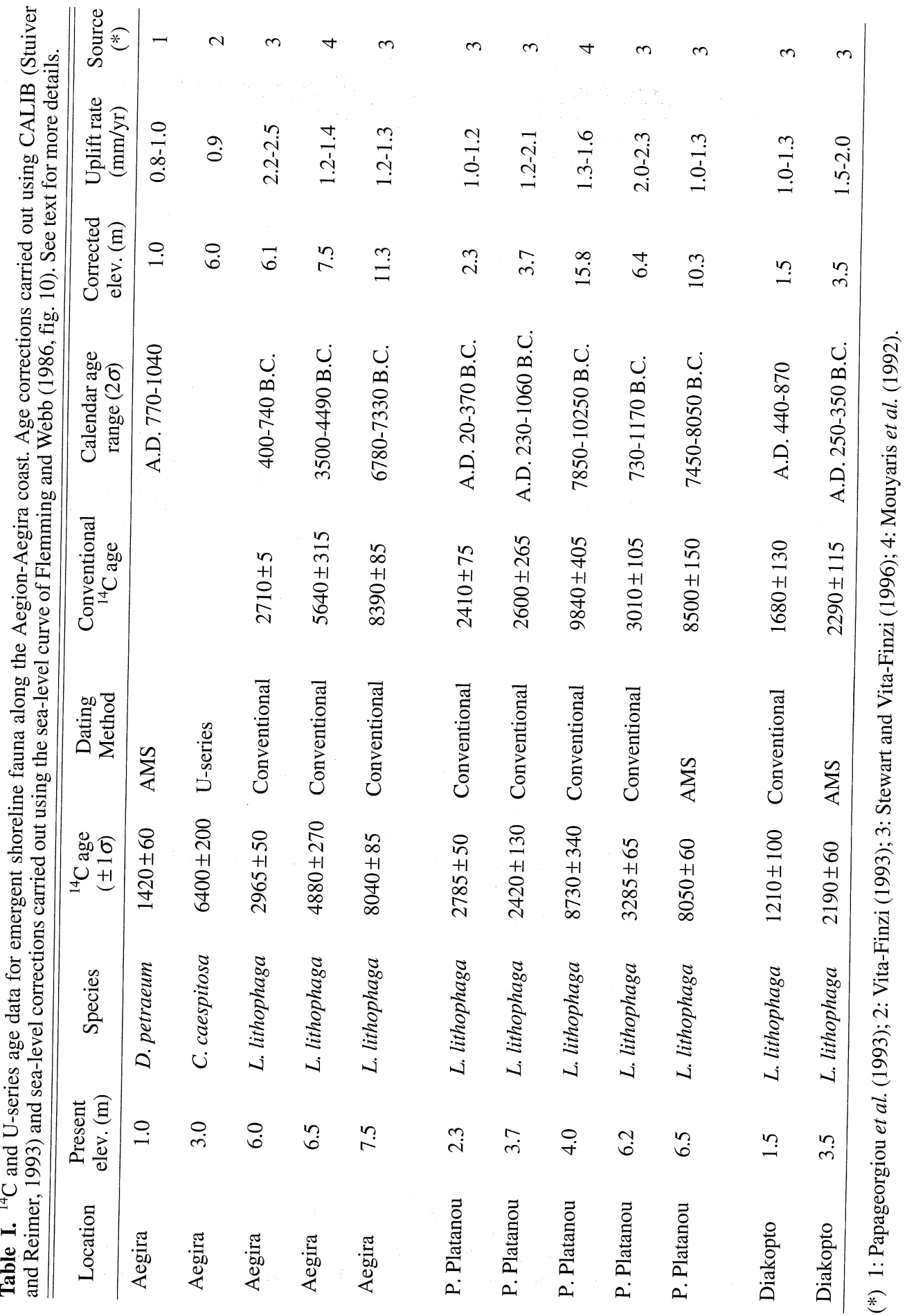



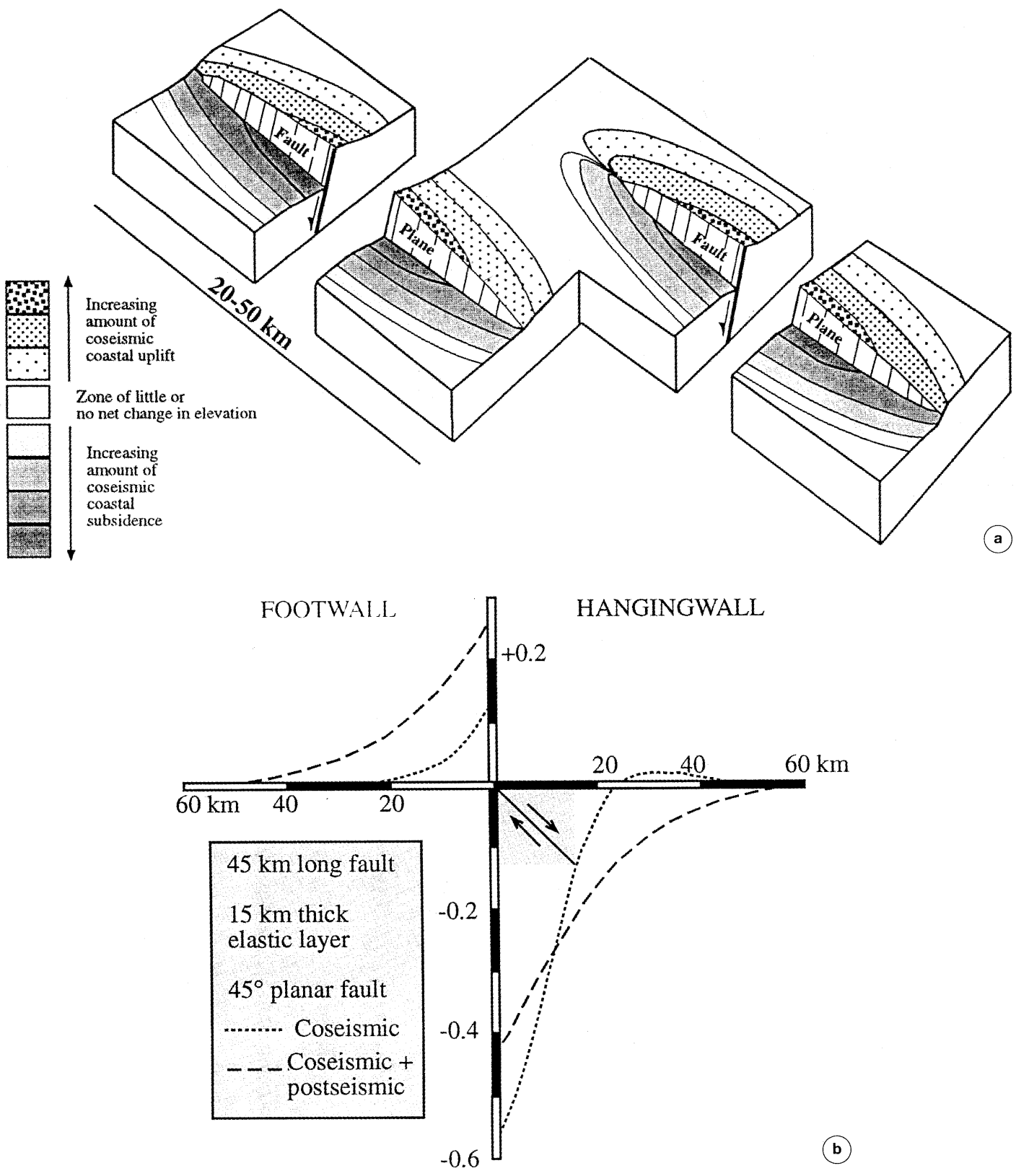

Fig. 5a,b. Figure illustrating the coseismic behaviour of normal faults. a) Idealised block diagram showing the effect of normal-fault segmentation on coastal uplift (from Collier and Gawthorpe, 1994, fig. 7). b) Generalised model profile showing the coseismic (dotted) and combined coseismic and postseismic (dashed) deformation associated with a normal fault dipping at $45^{\circ}$ and cutting an elastic layer of $15 \mathrm{~km}$ thickness (from King et al., 1988). 
segment tip (Aegira). Despite these contrasting structural positions, the Diakopto/Paralia Platanou and Aegira sites show no significant disparity in long-term uplift rates (table I). Indeed, if anything, coastal uplift rates within the Aegira «transfer zone» appears to exceed that recorded immediately inboard of the active fault. Such consistent emergence indicates that tectonic uplift along this coastal zone can not be explained solely by repeated coseismic dislocation of a fault segment which terminates around Akratas, because under this tendency the Aegira site should be an area of net slip deficit. Thus, it appears that at the scale of inquiry presented here, the coastal sites can be considered as uplifting as a broadly coherent unit.

Although comparable ranges of uplift rates for sites close to and distant from the main Eliki Fault segment fail to discriminate along- strike variations in Holocene fault activity, an age-height plot of dated elevated marine fauna (fig. 6) reveals apparent temporal changes in the rate of coastal uplift over the last 10000 years. In particular, the data can perhaps be viewed in terms of two pulses of enhanced tectonic activity, between 0-3000 year B.P. and pre-7-8000 year B.P., during which uplift rates are likely to have been $2.0-2.5 \mathrm{~mm} / \mathrm{yr}$. In contrast, these are separated by a $\sim 4-5000$ year long period of tectonic quiescence during which minimal uplift occurred. The most recent phase of tectonism, responsible for $\sim 6 \mathrm{~m}$ of uplift over the last 3000 years, is coincident with the two historical earthquake events attributed to the Eliki Fault. The next section, however, examines whether the uplift experienced during this period can be solely attributed to recurrent coseismic movements.

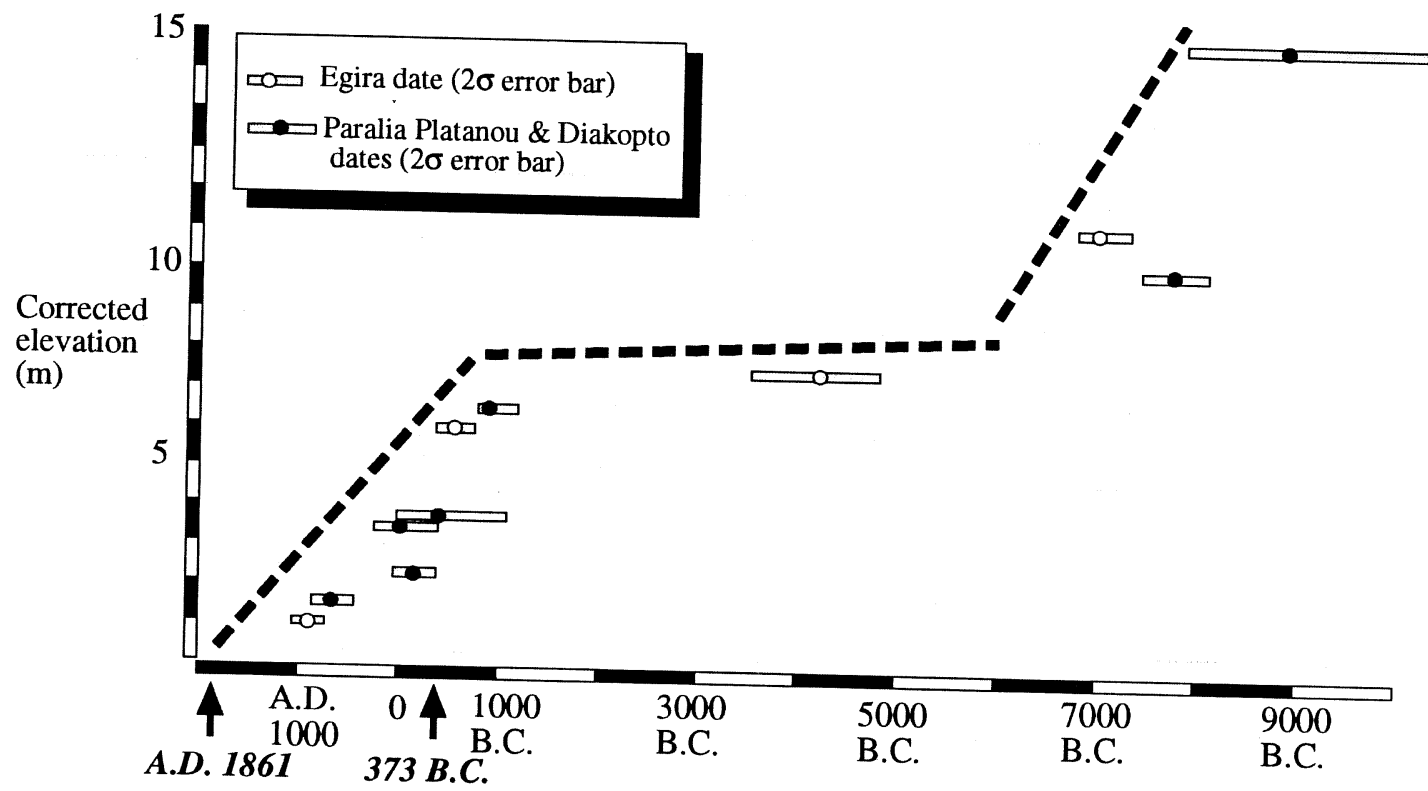

Age (Calender years)

Fig. 6. Age-height plot for elevated shoreline fauna along the proximal (Paralia Platanou and Diakopto) and distal (Aegira) portions of the Eliki Fault. Horizontal boxes show age errors at 2 standard deviations. Eustatic corrections after Flemming and Webb (1986, fig. 10) and age in calender years using the CALIB adjustment of by arrows. Thick dashed line and Reimer, 1993). Timing of the A.D. 1861 and 373 B.C. earthquakes shown quiescence during Holocene times. 


\section{Coseismic versus aseismic deformation}

Multiple fossil shorelines have in adjacent parts of the Central Aegean region been cited as evidence of punctuated metre-sized coastal uplift events and attributed to coseismic fault motions. Stiros et al. (1992), for example, interpreted an extensive, near-continuous notch, raised $0.7 \mathrm{~m}$ above present-day sea level, along the northern coast of Euboea Island as the product of coseismic uplift around 2500 year B.P. The lateral persistance of the fossil shoreline $(\sim 70 \mathrm{~km}$ long $)$, the intact state of elevated marine borings and the structural continuity of the coastal-bounding fault escarpment were cited as evidence of a coseismic origin. Similarly, Pirazzoli et al. (1994) ascribed a flight of four tidal notches cut into Mesozoic limestone cliffs on the Perachora Peninsula, Eastern Gulf of Corinth, to repeated uplift movements, each of about $0.8 \pm 0.3 \mathrm{~m}$, over the last 6400 years. Again the observation that associated $L$. lithophaga shells remained articulated and in growth position suggested that they were raised above wave action rapidly. In a part of the Mediterranean region where the tidal range is of the order of $0.5 \mathrm{~m}$, coseismic uplift is ex- pected to be at least this value to raise marine phenomena beyond the littoral zone.

Despite the recognition that the Aegion-Aegira zone clearly experiences movements generated by large earthquakes, and therefore that consequential uplift is likely to be episodic rather than uniform, Stewart and Vita-Finzi (1996), argue that uplift can not be the product of simply repeated coseismic displacements. They contend that while ground breaks associated with normal faulting earthquakes may be up to several metres in height, field and geodetic studies show that the proportion of this displacement which contributes to footwall uplift is generally restricted to only a few tens of centimetres (fig. 5b and table II). As a result, several tens of moderate magnitude $\left(M_{s} 6.0\right.$ 7.0) earthquakes, each contributing $0.2-0.3 \mathrm{~m}$ to coseismic uplift, are required during the last three millenia to produce the observed $6 \mathrm{~m}$ of coastal uplift. No such frequency is inferred from historical sources (Ambraseys and Jackson, 1990).

The inability to attribute recorded coastal emergence to repeated coseismic increments indicates that a «ncn-coseismic» uplift mechanism must be operating along the Eliki Fault. Support for this contention comes from archae-

Table II. Summary of the main characteristics of recent normal faulting earthquakes which highlights the disparity between coseismic subsidence and coseismic uplift for such events.

\begin{tabular}{|c|c|c|c|c|c|c|c|}
\hline Earthquake & Year & $M_{s}$ & $\begin{array}{l}\text { Rupture } \\
\text { length } \\
(\mathrm{km})\end{array}$ & $\begin{array}{l}\text { Maximum } \\
\text { offset } \\
(\mathrm{m})\end{array}$ & $\begin{array}{l}\text { Coseismic } \\
\text { uplift } \\
\text { (m) }\end{array}$ & $\begin{array}{l}\text { Coseismic } \\
\text { subsidence } \\
\quad(\mathrm{m})\end{array}$ & Sources \\
\hline Edgecumbe, NZ & 1987 & 6.6 & 7 & 2.5 & $<0.1$ & 1.5 & Beanland et al. (1990) \\
\hline Borah Peak, Idaho & 1983 & 7.3 & $>20$ & $2.5-2.7$ & $<0.3$ & 1.2 & $\begin{array}{l}\text { Stein and Barrientos (1985); } \\
\text { Crone et al. (1987) }\end{array}$ \\
\hline $\begin{array}{l}\text { Gulf of Corinth, } \\
\text { Greece }\end{array}$ & 1981 & $6.4-6.7$ & 15 & 1.5 & 0.2 & 1.5 & $\begin{array}{l}\text { Jackson et al. (1992); } \\
\text { Vita-Finzi and King (1985) }\end{array}$ \\
\hline $\begin{array}{l}\text { Hebgen Lake, } \\
\text { Montana }\end{array}$ & 1959 & 7.5 & 30 & 6.5 & 0.5 & $6-6.5$ & Koseluk and Bischke (1981) \\
\hline $\begin{array}{l}\text { Fairview Peak, } \\
\text { Nevada }\end{array}$ & 1954 & 7.1 & 24 & 3.5 & $0.1-0.3$ & 1.1 & $\begin{array}{l}\text { Slemmons (1957); } \\
\text { Savage and Hastie (1966) }\end{array}$ \\
\hline Eliki, Greece & 1861 & $?$ & $13-15$ & $2-2.4$ & $?$ & $?$ & Mouyaris et al. (1992) \\
\hline
\end{tabular}


ological and biological evidence at the ancient harbour of Aegira, where only half the $2 \mathrm{~m}$ of land uplift during the last 2000 years can be attributed to a coseismic movement (dated to A.D. 900-1200) (Papageorgiou et al., 1993). In addition, repeated levelling data over the last fifty years infers $20-30 \mathrm{~cm}$ of uplift for the Aegira region (Stiros, 1988). Such uplift may reflect regional aseismic movement, such as that proposed to accompany underplating along the Hellenic subduction zone (Roberts and Jackson, 1991; Collier et al., 1992). Equally, however, it may be the cumulative effect of distributed deformation accompanying moderate magnitude seismicity on other faults within the Western Gulf of Corinth. A likely «local» uplift mechanism, however, is that accompanying the aseismic portions of the earthquake cycle, in particular, postseismic deformation. Modelling of postseismic movements associated with normal faults shows that relaxation causes broad uplift centred on the fault itself and is capable of generating uplift equivalent to that achieved coseismically (King et al., 1988) (fig. 5b). Postseismic deformation accompanying the 1959 Hebgen lake earthquake, for example, resulted in $\sim 0.3 \mathrm{~m}$ of uplift over a broad area in the subsequent two decades, though there after uplift rapidly decreased (Reilinger, 1986).

It is likely that at least some of the coastal uplift recorded along the Eliki Fault reflect postseismic rebound in the immediate vicinity of the fault. Armijo et al. (1996) have elegantly modelled late Quaternary shoreline uplift in the Eastern Gulf of Corinth by flexural dislocation on the gulf-bounding fault, where long-term uplift rates are $\sim 1.5 \mathrm{~mm} / \mathrm{yr}$ (Keraudren and Sorel, 1987; Collier et al., 1992), comparable with the Holocene uplift rates reported here. This implies that fault-related footwall uplift can achieve the required coastal emergence without recourse to regional tectonic mechanisms. If this is the case, «documentation of postseismic rebound indicates that the deformation accumulated around a normal fault is not simply the sum of strains associated with elastic (slip) events» (Roberts and Yielding, 1994, p. 230), a recognition that clearly presents difficulties in isolating the palaeoseismic component from the composite coastal record. It also presents a difficulty in translating uplift rates into fault-slip rates, since the extent of hangingwall subsidence remains uncertain, partly because coseismic subsidence bears no empirically-determined relation to coseismic emergence and partly because net subsidence is reduced by postseismic recovery (for example, G.C.P. King, personal communication, suggests that the net ratio between footwall uplift and hangingwall subsidence may approach 50:50). In the absence of a more detailed understanding of the dynamics of normal faulting, coastal uplift rates, can only be used as a very approximate measure of fault-slip rates.

\section{Palaeoseismicity along the Eliki Fault}

The recognition that moderate magnitude normal-faulting earthquakes generate coseismic and postseismic uplift of around a few tens of centimetres (Stewart and Vita-Finzi, 1996), implies that the prominent notch level at +1.7 $\mathrm{m}$ is unlikely to be attributed to the A.D. 1861 event (as inferred from Mouyaris et al., 1992 and Vita-Finzi, 1992). This contention is supported by radiocarbon dating of $L$. lithophaga from a $+1.5 \mathrm{~m}$ high notch east of Diakopto, which dates the emergence of this erosional level to between A.D. 440 and A.D. 870. This age range overlaps with that derived from emergent vermetids collected at $+1 \mathrm{~m}$ near Aegira (Papageorgiou et al., 1993) (table I), suggesting that if the fresh, well-defined notch is to be attributed to a rapid dislocation of the coastline, it is most likely attributed to a coseismic event in the 8th-9th century A.D. Despite the uncertain age determination, the evidence points to an additional surface faulting event along the Eliki Fault between the two historically reported events of A.D. 1861 and 373 B.C.

Radiocarbon dating of fauna associated with the $+3.7 \mathrm{~m}$ notch level indicates that this surface may be correlatable with the 373 B.C. earthquake which destroyed ancient Helice. Thus while fauna immediately above and below this level yield age ranges which consistently predate and postdate, respectively, the 
historical event, lithophaga collected from the $+3.7 \mathrm{~m}$ level yields a calibrated age of 390 B.C. The very broad age range for $+3.7 \mathrm{~m}$ sample precludes a more confident correlation, but the coincidence of an overlapping age range and the well-defined nature of this erosional level strongly suggests that it is the morphological expression of this event. Note that there is no distinct morphological imprint of the A.D. 1861 event.

Uncertainties in attributing more minor notch levels to specific coastal uplift events warrants restriction of this discussion only to the two main notch levels of +1.7 and $+3.7 \mathrm{~m}$. It is likely, however, that higher notch levels may record pre-373 B.C. earthquakes (though not necessarily along the Eliki Fault) and that the Holocene uplift data may be used to tentatively bracket their age, though this is largely speculative. Nevertheless, the evidence provided by the major notch levels throws more light on the palaeoseismic history of the Eliki Fault. In particular, it suggests that at least 3 surface faulting events have occurred during the last 2500 years, requiring the previous estimate of recurrence interval of 1600 years (Mouyaris et al., 1992) to be revised. Instead, a more realistic estimate based on this study is around 1000 years. Such a recurrence interval, however, must be seen as characteristic of the recent intense phase of tectonic activity along the Eliki Fault and is not typical of its seismogenic behaviour throughout Holocene times. This recognition of alternating periods of tectonic activity and tectonic quiescence on the Eliki Fault, also documented from other studies of active normal faulting (e.g., McCalpin, 1993), illustrates the difficulties in deriving meaningful forecasts of earthquake incidence from palaeoseismic chronologies.

\section{Discussion and conclusions}

The Holocene coastal record of tectonic emergence in the footwall of the Eliki Fault is a poor discriminant of coseismic uplift events. For the most part, the record is based on erosional notches and elevated marine fauna which cannot be unambiguously correlated with former sea-levels. More importantly, the uniformity of uplift along the Eliki Fault, the minor contribution played by coseismic uplift in normal-faulting earthquakes and the absence of frequent surface faulting in the historical record, require the bulk of coastal uplift to be achieved through non-coseismic deformation (Stewart and Vita-Finzi, 1996). Although the precise nature of the deformation remains unclear, the involvement of a significant non-coseismic faulting component clearly obscures the size and timing of past earthquake events. Nevertheless, some important implications for the palaeoseismic behaviour of the Eliki Fault are inferred.

1) Morphological evidence suggests at least three surface faulting events occurred along the Eliki Fault during the past 2500 years. Although the size of these events cannot be reconstructed from the coastal record, the recognition of a new historical earthquake event around the 8th-9th century A.D. suggests that previous recurrence estimates of 1600 years need to be revised to around 1000 years.

2) The chronology of coastal emergence along the Eliki Fault indicates that marked changes in the rate of coastal uplift occurred during Holocene times. In particular, two phases of enhanced tectonic activity are identified (0-3000 year B.P. and pre-7-8000 year B.P.) during which uplift rates were around 2.0-2.5 mm/yr. These periods were separated by a 4-5000 year long period of tectonic quiescence during which uplift was minimal. Such clustering of earthquakes in time raises questions about the future timing of earthquakes along the Eliki Fault.

3) Finally, evidence of rapid Holocene uplift in the footwall of the offshore portion of the Eliki Fault raises the question of its seismic potential. Thus while the mapped $13-15 \mathrm{~km}$ long rupture and $\sim 2 \mathrm{~m}$ fault displacement of the A.D. 1861 event (Schmidt, 1879) is consistent with that expected of moderate magnitude $\left(\sim M_{s}=6.5\right)$ normal faulting events documented elsewhere in Central Greece (Roberts and Jackson, 1991), the coastal record suggests that the seismogenic fault may extend significantly offshore, making its true seismogenic length considerably greater. 


\section{Acknowledgements}

The study was undertaken with financial support of the Royal Society and Brunel University College and in collaboration with EC Environment project «Relative sea-level changes and extreme flooding events around European coasts». The paper has benefited from discussions with Claudio Vita-Finzi and Nick Ambraseys, and from critical reviews by Gianluca Valensise, Gerald Roberts and Spyros Pavlides. Paola Stewart is thanked for field support. This paper is a contribution to the I.U.G.S. Subcommission or Tectonic and Surface Processes Interactions.

\section{REFERENCES}

AmBraseys, N. and J.A. JACKSON (1990): Seismicity and associated strain of Central Greece between 1890 and 1988, Geophys. J. Int., 101, 663-708.

Armijo, R., B. Meyer, G.C.P. King, A. Rigo and D. PAPANASTASSIOU (1996): Quaternary evolution of the Corinth rift and its implications for the Late Cenozoic evolution of the Aegean, Geophys. J. Int. (in press).

BeAnland, S., G.H. Blick and D.J. Darby (1990): Normal faulting in a back-arc basin: geological and geodetic characteristics of the 1987 Edgecumbe earthquake, New Zealand, J. Geophys. Res., 95, 4693-4707.

BlanCHON, P. and J. SHAW (1995): Reef drowning during the last glaciation: evidence for catastrophic sea-level change and ice-sheet collapse, Geology, 23, 4-8.

COLlIER, R.E.L1. and R. GAWTHORPE (1994): Neotectonics, drainage and sedimentation in Central Greece: insights into coastal reservoir geometries in syn-rift sequences, in Hydrocarbon Habitat in Rift Basins, edited by J.J. LAMBIASE, Geological Society Special Publication No. 80, 165-181.

Collier, R.E.L., M.R. LeEder, P.J. Rowe and T.C. ATKINSON (1992): Rates of tectonic uplift in the Corinth and Megara Basins, Central Greece, Tectonics, 11, 1159-1167.

Crone, A.J., M.N. Machette, M.G. Bonilla, J.J. LienKaemper, K.L. PierCe, W.E. SCOTt and R.C. BUCKNAM (1987): Surface faulting accompanying the Borah Peak earthquake and segmentation of the Lost River Fault, Central Idaho, Bull. Seism. Soc. Am., 77, 739-770.

Dart, C.J., R.E.L. COllier, R. Gawthorpe, J.V.A. KELLER and G. NICHOLS (1994): Sequence stratigraphy of Pliocene-Quaternary synrift, Gilbert-type fan deltas, Northern Peloponnesos, Greece, Mar. Pet. Geol., 11, 545-560.

Doutos, T. and G. Poulimenos (1992): Geometry and kinematics of active faults and their seismotectonic significance in the Western Corinth-Patras rift (Greece), $J$. Struct. Geol., 14, 689-699.
FAIRBANKS, R.G. (1989): A 17000 year glacio-eustatic sea-level record - influence of glacial melting rates on the Younger Dryas event and deep-ocean circulation, Nature, 342, 637-642.

Ferentinos, G., G. Papatheodorou and M.B. Collins (1988): Sediment transport processes on an active submarine fault escarpment, Mar. Geol., 83, 43-61.

Flemming, N. and C.O. WebB (1986): Tectonic and eustatic coastal changes during the last 10000 years derived from archaeological data, Z. Geomorphol., 62 , 1-29.

JACKSON, J.A. (1994): Active tectonics of the Aegean region, Ann. Rev. Earth. Planet. Sci., 22, 239-271.

JACKSON, J.A., J. GAGNEPAIN, G. Houseman, G.C.P. King, P. Papadimitriou, C. Soufleris and J. VIRIEUX (1982): Seismicity, normal faulting and the geomorphological development of the Gulf of Corinth (Greece): the Corinth earthquakes of February and March 1981, Earth Planet. Sci. Lett., 57, 377-397.

KARFAKIS, Y. and N. MouYARIS (1988): Remote sensing and seismotectonic inspection of the West Corinthian Gulf - disasters during ancient times and seismic hazard, in Engineering Geology of Ancient Works, Monuments and Historical Sites, edited by P.G. MARINos and G.C. KoukIS (Balkema, Rotterdam), 1291-1299.

Keraudren, B. and D. Sorel (1987): The terraces of Corinth (Greece) - a detailed account of eustatic sealevel variations during the last 500000 years, Mar. Geol., 81, 99-107.

KING, G.C.P., R.S. SteIN and J.B. RundLe (1988): The growth of geological structures by repeated earthquakes, J. Geophys. Res., 93, 13307-13319.

KosELUK, R.A. and R.E. BISCHKE (1981): An elastic rebound model for normal fault earthquakes, J. Geophys. Res., 86, 1081-1090.

LABOREL, J. and F. LABOREL-DEGUEN (1994): Biological indicators of relative sea-level variations and co-seismic displacements in the Mediterranean region, $J$. Coastal Res., 10, 395-415.

McCAlPIN, J.P. (1993): Neotectonics of the northeastern Basin and Range margin, Western U.S.A., Z. Geomorph., suppl. 94, 137-158.

Mouyaris, N., D. PAPAStamatiou and C. Vita-Finzi (1992): The Helice Fault?, Terra Nova, 4, 124-129.

Papageorgiou, S., M. ARnold, J. LABOREL and S. STIROS (1993): Seismic uplift of the harbour of ancient Aigeira, Central Greece, Int. J. Nautical Archaeol., 22 275-281.

PIRAzZOLI, P.A. (1986): Marine notches, in Sea-level research: a manual for the collection and evaluation of data, edited by O. VAN DE PLASSCHE, Geo Books, Norwich, 361-400.

Pirazzoli, P.A., S.C. Stiros, M. Arnold, J. LAborel, F. LABOREL-DEguen and S. PAPAGEORGIOU (1994): Episodic uplift deduced from Holocene shorelines in the Perachora Peninsula, Corinth area, Greece, Tectonophysics, 229, 201-209.

Poulimenos, G. (1993): Tectonics and sedimentation in the Western Corinth graben, Greece, $N$. Jb. Geol. Palaeont. Mh., 10, 607-630.

Poulimenos, G., G. Albers and T. Doutsos (1989): Neotectonic evolution of the central section of the Corinth Graben, Z. dt. Geol. Ges., 140, 173-182. 
REILINGER, R. (1986): Evidence for postseismic viscoelastic relaxation following the $1959 M=7.5$ Hebgen Lake, Montana, earthquake, J. Geophys. Res., 91, 9488-9494.

RoBerts, A.M. and G. YIELDING (1994): Continental extensional tectonics, in Continental Deformation, edited by P.L. HANCOCK (Pergamon Press, Oxford), 223250.

Roberts, G.P. and R. GAwTHORPE (1994): Strike variation in deformation and diagenesis along segmented normal faults: an example from the Eastern Gulf of Corinth, Greece, in Hydrocarbon Habitat in Rift Basins, edited by J.J. LAMBIASE, Geological Society Special Publication No. 80, 57-74.

Roberts, G.P. and I. Koukouvelas (1996): Structural and seismological segmentation of the Gulf of Corinth fault system: implication for models of fault growth, Annali di Geofisica, 39, 619-646.

RoBERTS, S. and J.A. JACKSON (1991): Active normal faulting in Central Greece: an overview, in The Geometry of Normal Faults, edited by A.M. RoBERTS, G. YIELDING and B. FREEMAN, Geological Society Special Publication No. 56, 125-142.

SAvaGe, J.C. and L.M. HAstie (1966): Surface deformation associated with dip-slip faulting, J. Geophys. Res., 71, 4897-4904.

SchmidT, J. (1879): Studien uber Erdbeben, Leipzig, 6883.

SLemmons, D.B. (1957): Geological effects of the Dixie Valley - Fairview Peaks, Nevada, earthquakes of 1954, Bull. Seism. Soc. Am., 47, 353-375.

SteIN, R.S. and S.E. BARRIENTOS (1985): Planar high-angle faulting in the Basin and Range: geodetic analysis of the 1983 Borah Peak, Idaho, earthquake, J. Geophys. Res., 90, 11355-11366.
STEWART, I.S. and P.L. HANCOCK (1990): Brecciation within neotectonic normal fault zones cutting carbonates in the Aegean region, in Deformation Mechanisms, Rheology and Tectonics, edited by R.J. KNIPE and E. RutTer, Spec. Publ. Geol. Soc. London, 54, 105-112.

STEWART, I.S. and C. ViTA-FINZI (1996): Coastal uplift on active normal faults: the Eliki Fault, Greece, Geophys. Res. Lett., $\mathbf{X}$ (accepted).

STIROS, S.C. (1988): Model for the North Peloponnesian (Central Greece) uplift, J. Geodyn., 9, 199-214.

Stiros, S.C., M. Arnold, P.A. Pirazzoli, J. LABorel, F. LABOREL and S. PAPAGEORGIOU (1992): Historical coseismic uplift on Eoboea Island, Greece, Earth Planet. Sci. Lett., 108, 109-117.

Stuiver, M. and P.J. ReImer (1993): Extended ${ }^{14} \mathrm{C}$ database and revised CALIB radiocarbon program, $R a$ diocarbon, 35, 215-230.

VITA-FINZI, C. (1992): Radiocarbon dating of late Quaternary fault segments and systems, J. Geol. Soc. London, 149, 257-260.

VITA-FINZI, C. (1993): Evaluating late Quaternary uplift in Greece and Cyprus, in Magmatic Processes and Plate Tectonics, edited by H.M. Prichard, T. AlabASTER, N.B.W. HARRIS and C.R. NEARY, Geological Society Special Publication No. 76, 417-424.

VITA-FINZI, C. and G.C.P. KING (1985): The seismicity, geomorphology and structural evolution of the Corinth area of Greece, Philos. Trans. R. Soc. London, Ser. A, 314, 379-407.

Zhang, P., D.B. Slemmons and F. MaO (1991): Geometric pattern, rupture termination and fault segmentation of the Dixie Valley-Pleasant Valley active normal fault system, Nevada, U.S.A., J. Struct. Geol., 13, 165176. 